\title{
Pemanfaatan Limbah Cangkang Buah Nipah Menjadi Masker Gel Peel Off Pada Ibu-Ibu PKK Kelurahan Kampung Laut Tanjung Jabung Timur
}

\author{
Diah Riski Gusti ${ }^{1}$, Uce Lestari ${ }^{2}$, Intan Lestari ${ }^{3}$, Indra Lasmana Tarigan ${ }^{4}$ \\ 1,3,4 Program Studi Kimia Fakultas Sains dan Teknologi Universitas Jambi \\ ${ }^{2}$ Program Studi Farmasi Fakultas Kedokteran dan Ilmu Kesehatan Universitas Jambi \\ Corresponding author: ucelestari@unja.ac.id
}

\begin{abstract}
ABSTRAK.
Kampung Laut merupakan salah satu Kelurahan yang berada di Kecamatan Kuala Jambi Tanjung Jabung Timur yang memiliki sumber daya alam yang tidak termanfaatkan limbahnya yaitu serabut cangkang buah dari tanaman nipah. Selama ini masyarakat Kampung Laut hanya memanfaatkan buah nipah sebagai produk olahan pangan seperti dodol, tetapi limbah dari serabut cangkang buah nipah terbuang dan tidak dimanfaatkan. Cangkang buah nipah yang mengandung selulosa tinggi sehingga jika diolah menjadi arang aktif berubah menjadi karbon yang memiliki efektifitas kemampuan penyerapan kotoran, racun dan minyak pada kulit. Dengan melihat potensi ini maka muncul ide untuk mengolah arang aktif cangkang buah nipah menjadi produk kosmetik masker gel peel off. Tujuan kegiatan pengabdian kepada masyarakat ini adalah mampu memberi nilai jual tanaman nipah khususnya cangkang buah nipah yang terbuang, meningkatkan pengetahuan masyarakat mengenai cara pembuatan masker gel peel off, dan memaksimalkan sumber daya manusia di kelurahan Kampung Laut. Metode yang digunakan dalam pelatihan ini, yaitu penyuluhan tentang tanaman nipah, pembuatan masker gel peel off, dan aplikasi masker gel peel off pada wajah. Kegiatan ini menghasilkan produk kosmetik masker gel peel off berbahan dasar natural dari arang aktif cangkang buah nipah. Manfaat dari PPM ini yang dapat meningkatkan nilai jual dari tanaman nipah, serta meningkatkan kreativitas sumber daya manusia di Kelurahan Kampung Laut, Kecamatan Kuala Jambi, Kabupaten Tanjung Jabung Timur.
\end{abstract}

Kata Kunci: Arang Aktif, Cangkang Nipah, Masker Gel Peel Off

\section{PENDAHULUAN}

Masyarakat Kelurahan Kampung Laut mayoritas 80\% suku melayu dengan mata pencarian sebagai nelayan dan petani serta banyak beraktifitas diluar rumah. Tumbuhan nipah yang tumbuh di sekitar masyarakat tersebut memberikan peluang yang sangat besar untuk mendapatkan produk teknologi tepat guna yang berbahan dasar nipah, yaitu pada cangkang buah buah nipah yang terbuang dan tidak termanfaatkan.

Nipah (Nypa fraticans Wurmb) merupakan salah satu tanaman yang banyak tumbuh pada daerah hutan mangrove dan dimanfaatkan untuk melindungi daratan/pantai dari abrasi air laut (Baharudin dan Taskirawati, 2009). Selama ini cangkang buah nipah sering diabaikan oleh masyarakat yang tinggal di Kampung Laut dan masih dianggap sebagai limbah yang terbuang dan tidak dapat dimanfaatkan. Masyarakat hanya mengolah buah nipahnya saja sebagai produk olahan pangan seperti dodol.

Cangkang buah nipah yang terbuang mengandung selulosa tinggi sehingga jika diolah menjadi arang aktif berubah menjadi karbon yang memiliki efektifitas kemampuan penyerapan kotoran, racun dan minyak pada kulit (Mulyadi dkk, 2014). Dengan adanya perkembangan teknologi maka cangkang buah nipah yang telah diolah menjadi arang aktif dapat memberikan nilai tambah ekonomi yang besar ditinjau dari penggunaan salah satu nya sebagai produk kosmetik yaitu masker gel peel off. 
Dalam keadaan sehari-hari kita banyaknya masyarakat yang melakukan aktivitas diluar rumah dimana wajah sering terpapar oleh debu, kotoran yang menempel pada kulit wajah, sehingga dapat bermasalah bagi kesehatan kulit wajah. Walaupun warnanya hitam, masker gel peel off ini diharapkan banyak diminati, khususnya bagi mereka yang punya masalah kesehatan kulit wajah ( Lestari dkk, 2019a).

Hasil penelitian sebelumnya menunjukkan bahwa masker gel peel off arang aktif cangkang nipah lebih efektif menyerap kotoran dibandingkan masker gel peel off komersil. Tujuan kegiatan pengabdian kepada masyarakat ini adalah mampu memberi nilai jual tanaman nipah khususnya cangkang buah nipah yang terbuang, meningkatkan pengetahuan masyarakat mengenai cara pembuatan masker gel peel off, dan memaksimalkan sumber daya manusia di kelurahan Kampung Laut.

\title{
METODE PELAKSANAAN
}

\section{Waktu dan tempat}

Pembuatan arang aktif cangkang buah nipah secara fisika dibuat pada laboratorium Agroindustri dan tanaman Obat serta laboratorium Lingkungan dan Geokimia Fakultas Sains dan Teknologi, Universitas Jambi. Penyuluhan atau sosialisasi dan aplikasi pengolahan dan penggunaan produk kosmetik masker gel peel off yang telah dilaksanakan pada tanggal 19 Agustus 2020 di Aula Kelurahan Kampung Laut, Kecamatan Kuala Jambi, Kabupaten Tanjung Jabung Timur.

\begin{abstract}
Alat dan Bahan
Adapun alat yang digunakan terdiri dari lampu spritus, kaki tiga, asbes, beaker glass, timbangan digital, spatel, batang pengaduk, lumpang dan alu, kaca arloji, kertas perkamen, wadah plastik, gelas ukur, pipet tetes. Bahan yang digunakan adalah arang aktif cangkang buah nipah, PVA, PVP, Propilenglikol, Metil Paraben, Propil Paraben, Oleum Rosae, Etanol 70\%, Aquadest
\end{abstract}

\section{Prosedur kerja}

Berikut adalah program kerja yang dilaksanakan dalam kegiatan pengabdian kepada masyarakat ini: 1). Pembuatan arang aktif dari cangkang buah nipah secara fisika 2). Sosialisasi pemanfaatan arang aktif cangkang buah nipah sebagai bahan baku masker gel peel off 3). Pemutaran Video teknologi pengolahan masker gel peel off dengan bahan baku arang aktif cangkang buah 4). Aplikasi produk kosmetik dari arang aktif cangkang buah nipah.

\section{Pengolahan Arang Aktif Cangkang Buah Nipah}

Sampel limbah cangkang buah nipah diperoleh dari Kampung Laut. Serabut dan cangkang dipisahkan dari buah, ditimbang dulu $2 \mathrm{~kg}$ kemudian dicuci dengan air mengalir kemudian dijemur hingga bobotnya konstan. Cangkang buah nipah yang telah kering kemudian dikarbonisasi dengan pembakaran dengan api bebas hingga menjadi arang, kemudian arang didinginkan dan digrinder menjadi serbuk arang, kemudian diayak dengan ayakan 200 mesh. Arang diaktivasi secara fisika. Serbuk arang aktif dimasukkan dalam cawan penguap ke dalam furnace pada suhu $750^{\circ} \mathrm{C}$ selama 3 jam (Pujiyanto,2010)

\section{Penentuan uji daya serap Arang aktif secara kualitatif terhadap metilen biru}

Untuk mengetahui kemampuan adsorpsi karbon aktif maka dilakukan uji adsorpsi terhadap metilen biru. Penentuan daya adsorpsi karbon aktif terhadap metilen blue dengan menimbang karbon aktif sebanyak 0,1 gram lalu ditambahkan larutan metilen blue $100 \mathrm{ppm}$ sebanyak $20 \mathrm{~mL}$ kemudian ditempatkan dalam erlenmeyer $50 \mathrm{ml}$ dan ditutup alumunium foil, sampel diaduk menggunakan magnetik stirrer selama 15 menit dan didiamkan selama 30 menit dengan kecepatan 100 rpm, kemudian disaring, dan dilihat perubahan warna yang terjadi (Purwanto, 2011 dan Anonim, 2009) 
Tabel 1. Formula Masker Gel Peel Off

\begin{tabular}{lcl}
\hline \multicolumn{1}{c}{ Bahan } & Konsentrasi & \multicolumn{1}{c}{ Fungsi } \\
\hline Arang Aktif Cangkang Nipah & 1,5 & Pembersih kotoran \\
PVA & 15 & Gelling agent \\
PVP & 5 & Bahan pengikat \\
Propilenglikol & 10 & Humektan \\
Metil Paraben & 0.2 & Pengawet \\
Propil Paraben & 0.1 & Pengawet \\
Oleum Rosae & 0.1 & Pewangi \\
Etanol 70\% & 15 & Pelarut \\
Aquadest & Ad 100 & Pelarut \\
\hline
\end{tabular}

\section{Proses Pembuatan Masker Peel Off}

Pembuatan sediaan masker gel peel off dimulai dengan cara dikembangkannya PVA (masa A) dalam wadah dengan aquadest hangat $\left(80^{\circ} \mathrm{C}\right)$, selanjutnya dalam tempat yang lain PVP dikembangkan dalam aquadest dingin hingga mengembang (masa B). Metil paraben dan propil paraben dilarutkan dengan propilenglikol (masa C). Masa B dan C secara berturut-turut dimasukkan kedalam bahan A lalu diaduk hingga homogen dengan kecepatan konstan. Arang aktif cangkang nipah ditambahkan sedikit demi sedikit ke dalam campuran bahan A, B dan C sambil terus diaduk, kemudian ditambahkan etanol 70\% dan pewangi sedikit demi sedikit, diaduk kembali, kemudian dimasukkan kedalam wadah (Lestari et all, 2019b).

\section{Aplikasi Penggunaan Masker Gel Pell Off}

Pembersih (Cleansing)

Masker gel peel off arang aktif cangkang buah nipah dapat mengangkat kotoran yang bersifat lemak, minyak maupun debu dan memiliki sifat yang dapat menetralkan kembali kondisi $\mathrm{pH}$ kulit yaitu antara 6-7. Pembersih dapat digunakan untuk perawatan sehari-hari ataupun perawatan secara berkala (Tresna, 2010)

Pelembab (Moisturizing)

Masker gel peel off arang aktif cangkang buah nipah dapat berfungsi sebagai Pelembab. Bertujuan untuk memberikan kelembaban pada kulit yang dibutuhkan bagi sel-sel dibawah permukaan kulit. Masker gel peel off mengandung propilen glikol yang dapat menarik air dari bawah kulit sambil mencegah penguapan. Pemakaian secara teratur dapat mempertahankan kondisi kulit terutama untuk jenis kulit kering (Tresna, 2010).

Pengangkatan Komedo

Penggunaan masker gel peel off arang aktif cangkang buah ini merupakan pembersihan yang mendalam (deep cleansing), karena dapat mengeluarkan komedo pada kulit sehingga pori pori kulit menjadi kecil. Selain itu masker gel peel off mengandung butiran-butiran kecil yang dapat membantu pengelupasan sel kulit mati pada saat dioleskan pada wajah (Tresna, 2010).

\section{Pencerah kulit}

Penggunaan masker gel peel off arang aktif jika dilakukan secara berkala dapat mencerahkan kulit wajah karena adanya kandungan karbon dalam arang aktif cangkang nipah sebagai penyerap kotoran yang dapat menghilangkan kontaminan berbasis organik serta beberapa kontaminan anorganik sehingga kulit menjadi bersih dan cerah (Tresna,2010) 


\section{HASIL DAN PEMBAHASAN}

Hasil yang dicapai dalam kegiatan pengabdian kepada masyarakat ini adalah terlaksananya sosialisasi dan aplikasi penggunaan dan penggunaan masker gel peel off dengan bahan dasar arang aktif cangkang buah nipah kepada ibu-ibu PKK Kelurahan Kampung Laut, Kecamatan Kuala Jambi, Kabupaten Tanjung jabung Timur.

Kegiatan ini telah diawali dengan melakukan koordinasi tim Pengabdian Pada Masyarakat (PPM) dengan Lurah Kampung Laut dengan kesepakatan menjadi mitra berdasarkan surat No: 073/30/KP/2020 tanggal 26 Februari 2020 perihal: Pernyataan kesediaan mitra dalam pelaksanaan PPM dengan judul "Pelatihan Dan Aplikasi Pemanfaatan Arang Aktif Cangkang Nipah Menjadi Masker Gel Peel Off Pada Ibu -Ibu PKK Kelurahan Kampung Laut Tanjung Jabung Timur".

Sasaran dari koordinasi ini adalah ibu-ibu PKK Kelurahan Kampung Laut dengan tujuan agar mereka ikut berpartisipasi dalam kegiatan PPM mendapatkan hasil pentingnya kegiatan PPM ini dalam memanfaatkan cangkang buah nipah yang terbuang, meningkatkan pengetahuan masyarakat mengenai cara pembuatan masker gel peel off, dan memaksimalkan sumber daya manusia di kelurahan Kampung Laut.

\section{Pengolahan Arang Aktif Cangkang Buah Nipah}

Sampel cangkang buah nipah diambil disepanjang jalan Kampung Laut. Cangkang buah nipah kemudian dipisahkan dari isinya . Cangkang buang nipah ditimbang $2 \mathrm{~kg}$ lalu dicuci dan dijemur hingga bobotnya konstan. Diperoleh cangkang buah nipah dengan berat menjadi 530 gram. Tahap selanjutnya adalah pembuatan arang (karbonasi). Pada tahap ini dilakukan dengan cara pembakaran dengan api bebas hingga menjadi arang. Arang yang jadi kemudian didinginkan dan digrinder menjadi serbuk arang, dan diayak dengan ayakan 200 mesh. Kemudian arang diaktivasi secara fisika. Serbuk arang aktif dimasukkan dalam cawan penguap ke dalam furnace pada suhu $750^{\circ} \mathrm{C}$ selama 3 jam. Arang aktif cangkang buah nipah yang diperoleh 180,33 gram dengan nilai rendemen sebesar 0,045\%.

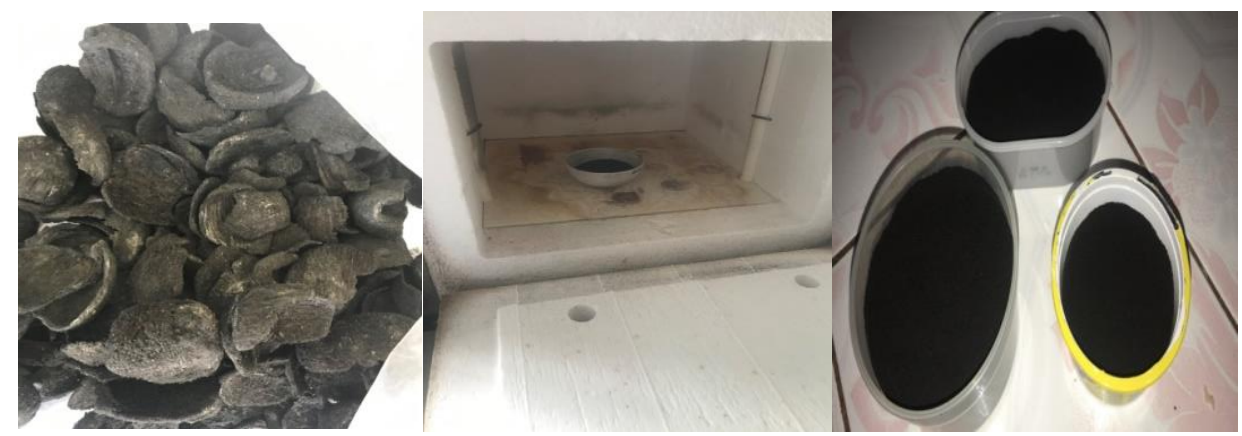

Gambar 1. Aktifasi Arang Cangkang buah nipah dengan menggunakan alat furnace

\section{Penentuan Uji Daya Serap Arang Aktif Secara Kualitatif dengan Metilen Biru}

Pengujian ini dilakukan dengan tujuan untuk mengetahui seberapa besar daya serap karbon aktif secara kualitatif, yaitu hanya dengan melihat perubahan warna terjadi pada metilen biru yang telah dilarutkan dengan serbuk arang aktif. Dari hasil yang telah dilakukan, warna biru dari metilen biru memudar setelah dilarutkan dengan serbuk arang aktif. Menurut Jawnkoska daya serap arang aktif terhadap metilen biru menunjukkan kemampuan adsorbsi arang aktif untuk molekul molekul yang memiliki ukuran yg mirip metilen biru.

\section{Pembuatan Masker Gel Peel Off Arang Aktif Cangkang Nipah}

Pembuatan sediaan masker gel peel off dimulai dengan cara dikembangkannya PVA sebanyak 5 gram (masa A) dalam wadah dengan aquadest hangat $\left(80^{\circ} \mathrm{C}\right)$, selanjutnya dalam tempat yang lain PVP sebanyak 5 gram dikembangkan dalam aquadest dingin hingga mengembang (masa B). Metil paraben sebanyak $0.2 \%$ dan propil paraben sebanyak $0.1 \%$ dilarutkan ke dalam 10 $\mathrm{mL}$ propilenglikol (masa $\mathrm{C}$ ). Masa $\mathrm{B}$ dan $\mathrm{C}$ secara berturut-turut dimasukkan kedalam bahan A lalu diaduk hingga homogen dengan kecepatan konstan. Sebanyak 1.5 gram arang aktif 
cangkang nipah ditambahkan sedikit demi sedikit ke dalam campuran bahan A, B dan C sambil terus diaduk, kemudian ditambahkan etanol $70 \%$ sebanyak $15 \mathrm{~mL}$ dan pewangi sedikit demi sedikit, diaduk kembali, kemudian dimasukkan kedalam wadah (Lestari et all, 2019a)

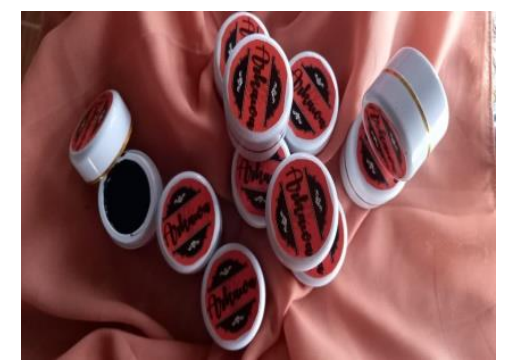

Gambar 2. Masker Gel Peel Off

\section{Sosialisasi Teknologi Pengolahan Masker Gel Peel Off Dengan Bahan Baku Arang Aktif Cangkang Buah Nipah}

Keadaan Pandemi Covid 19 ini menjadi kendala dalam pelaksanaan PPM, tetapi dengan adanya surat rekomendasi permohonan izin mengadakan acara pelatihan dari gugus covid 19 dan camat Kuala Jambi dengan nomor 100/352/Pem-KJ/VIII/2020 akhirnya pelaksanaan PPM ini mendapatkan izin dan rekomendasi dengan ketentuan mengikuti protocol kesehatan.

Adapun sasaran dari sosialisasi teknologi pengolahan kosmetik masker gel peel off dengan bahan baku arang aktif cangkang buah nipah adalah ibu-ibu PKK Kelurahan Kampung Laut yang ikut berpartisipasi dalam pelaksanaan kegiatan ini berjumlah kurang lebih 30 orang.

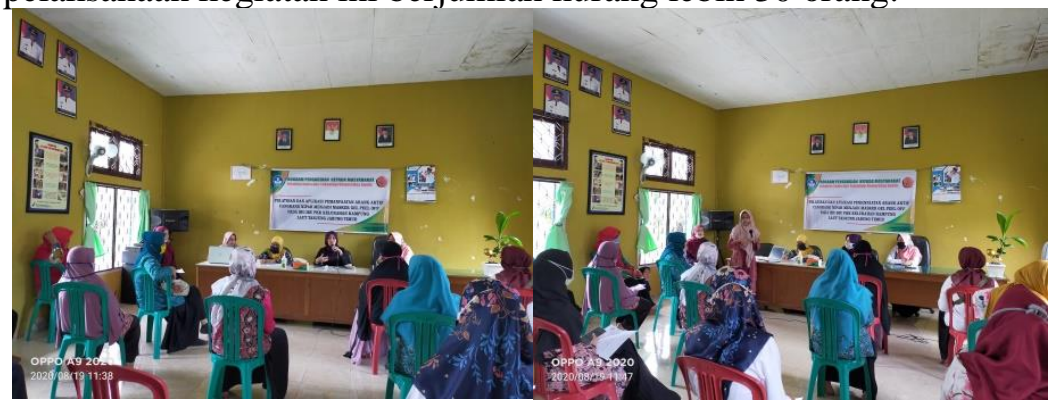

Gambar 3. Peserta Sosialisasi

Ibu-ibu PKK Kelurahan Kampung Laut sangat antusias dan aktif dalam mengikuti kegiatan ini dengan banyak memberikan pertanyaan terkait dari pemanfaatan arang aktif cangkang buah nipah sebagai bahan baku produk kosmetik masker gel peel off yang menjadi inovasi terbaru sebagai produk untuk perawatan kulit wajah yang dapat memberikan manfaat yang besar terhadap kesehatan kulit dan mencegah penuaan dini bagi ibu-ibu dizaman sekarang. Dimana selama ini ibu-ibu PKK tidak mengetahui bahwa limbah serabut cangkang nipah setelah pembuatan dodol dari isi nipah, ternyata limbahnya memberikan manfaat yang luar biasa, sehingga tidak ada bagian dari tanaman nipah yang tidak termanfaatkan. Semua bagian tanaman nipah dapat dimanfaatkan seluruhnya baik seperti lidi dan daun nipah, air nipah, buah nipah, cangkang nipah ataupun bunga nipah.

Selama ini masyarakat Kampung Laut hanya memanfaatkan lidi nipah untuk sapu, daun nipah untuk atap rumah, air nipah untuk gula merah dan garam, buah nipah untuk dodol dan manisan ataupun bunga nipah sebagai pewarna batik saat ini sedang dikembangkan dan tidak memanfaatkan serabut dan cangkang sebagai produk kosmetik.

Dari hasil sosialisasi pada kegiatan pengabdian kepada masyarakat ini dapat menambah wawasan dan pengetahuan masyarakat dalam hal cara pengolahan arang aktif dari cangkang buah nipah sebagai bahan dasar masker gel peel off. Diharapkan setelah sosialisasi ini masyarakat dapat membuka usaha lapangan pekerjaan dengan pembentukan UMKM industry kosmetik sehingga dapat menambah pendapatan masyarakat disekitar Kampung Laut dan mampu mengeksplorasi tanaman nipah menjadi produk kosmetik yang memiliki nilai ekonomi yang tinggi. Selain itu kosmetik masker gel peel off yang telah diolah dapat digunakan untuk kalangan sendiri ataupun keluarga. 


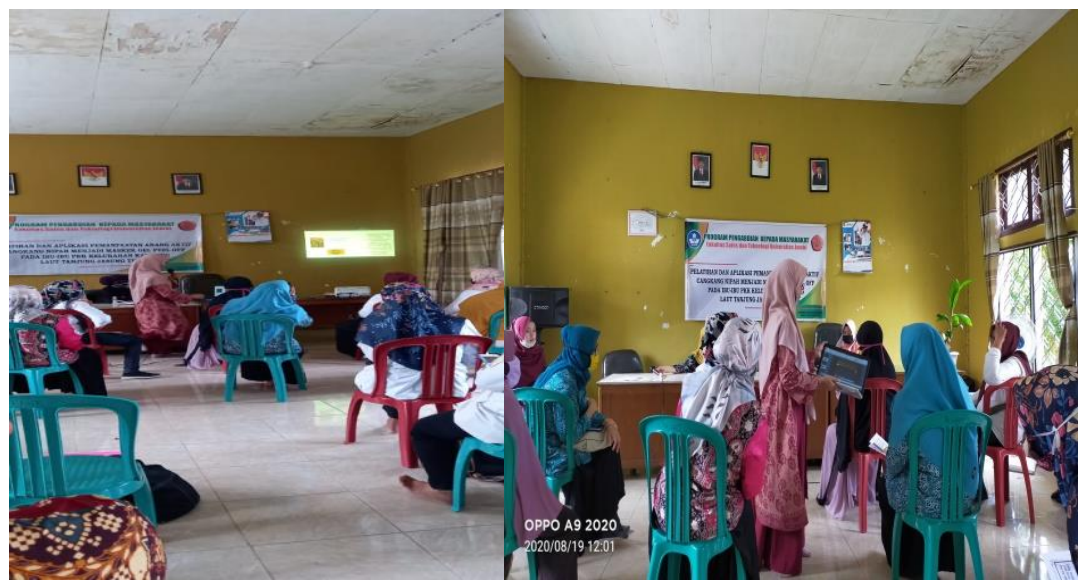

Gambar 4. Penyuluhan tentang masker gel peel off dengan bahan dasar arang aktif

\section{Aplikasi Penggunaan Masker Gel Peel Off Arang Aktif Cangkang Buah Nipah}

Setelah acara sosialisasi dilanjutkan pemberian masker gel peel off secara gratis kepada ibu-ibu PKK kelurahan Kampung Laut dimana ibu-ibu PKK mengaplikasikan secara langsung penggunaan masker gel peel off dan merasakan manfaat dari masker gel peel off. Adapun manfaat yang dirasakan setelah penggunaan masker gel peel off selama 15 menit oleh ibu-ibu PKK adalah kulit terasa lembut, komedo yang ada terangkat, kulit terasa bersih dan segar.

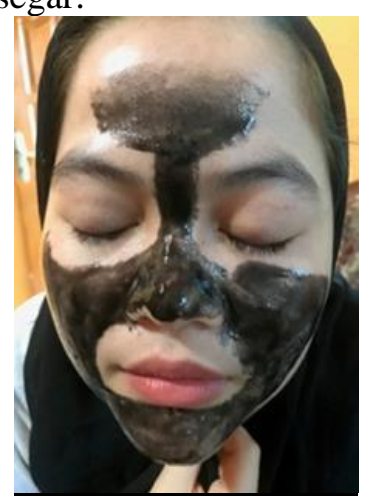

Gambar 5. Aplikasi Masker Gel Pel Off

Setelah penggunaan masker gel peel off selama 4 minggu dilakukan evaluasi terhadap penggunaannya melalui handphone ternyata ibu-ibu PKK Kampung Laut merasakan kenyamanan dalam penggunaan masker, kulit menjadi lebih cerah, kulit menjadi kencang, kulit menjadi bersih tanpa flek hitam, komedo tidak ada, pori-pori mengecil. Dari hasil aplikasi ini maka ibu-ibu PKK berharap untuk kedepannya tim PPM ini mendampingi dalam pembuatan masker gel peel off sehingga mereka dapat menghasilkan produk masker gel peel off yang memenuhi syarat dan standard. Kedepannya berharap dengan adanya bantuan pemerintah Tanjab Timur nantinya dapat membentuk UMKM dibidang industry kosmetik.

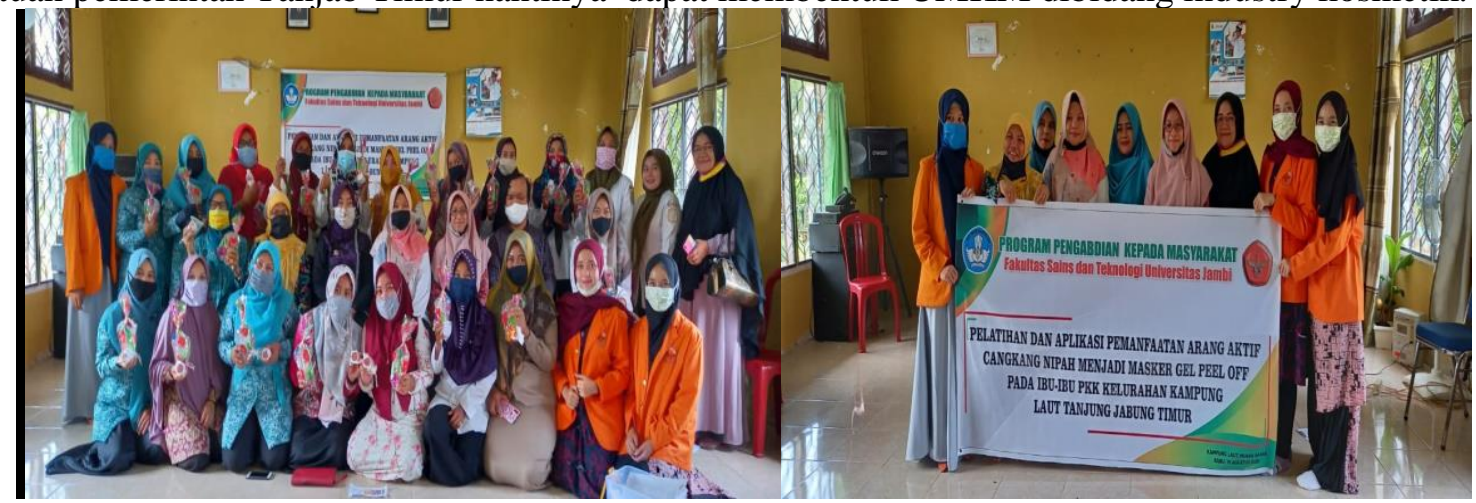

Gambar 6. Foto bersama 


\section{KESIMPULAN}

Hasil dari kegiatan sosialisasi dan aplikasi penggunaan masker gel peel off dari bahan dasar arang aktif cangkang buah nipah sebagai inovasi terbaru produk kosmetik dapat disimpulkan bahwa kegiatan ini memberikan pengetahuan lebih tentang manfaat arang aktif cangkang buah nipah mempunyai nilai dan manfaat yang besar dalam perawatan kulit wajah serta membuka peluang usaha industri kecil kosmetika serta meningkatkan kreativitas sumber daya manusia ibu-ibu PKK kelurahan Kampung Laut, Kecamatan Kuala Jambi, Kabupaten Tanjung jabung Timur

\section{UCAPAN TERIMAKASIH}

Terima kasih untuk pihak yang telah membantu baik dana ataupun support terutama pihak Lurah Kampung Laut, Camat Kampung Laut, PKK kelurahan Kampung Laut dan PKK Kecamatan Kuala Jambi dan Rektor Universitas Jambi, LPPM Universitas Jambi serta Dekan Fakultas Sains dan Teknologi Universitas Jambi dan semua pihak yang terkait sehingga pelaksanaan PPM ini terlaksana dengan biak dan laancar.

\section{DAFTAR PUSTAKA}

Baharudin dan Taskirawati. 2009. Hasil Hutan Bukan Kayu, Fakultas Kehutanan Universitas Hassanudin, Makassar.

Mulyadi, A.F., I.A. Dewi dan P. Deoranto. 2014. Pemanfaatan Kulit Buah Nipah Untuk Pembuatan Briket Bioarang Sebagai Sumber Energi Alternatif. Jurnal Teknologi Pertanian. 14(1):65-72.

Lestari, U., Y.A. Jesika dan Muhaimin. 2019a. Formulasi Masker Gel Peel Off Arang Aktif Cangkang Kelapa Sawit (Elaeis guineensis Jacq) Sebagai Pembersih Wajah Dengan Basis Polivinil Alkohol (PVA). Jurnal Talenta Conference Series: Science and Tecnology (ST). 2(2).

Lestari, U., F. Farid dan A.Fudholi. 2019b. Formulation and Effectivity Test of Deodorant From Activated Charcoal of Palm Shell As Excessive Sweat Adsorbent On Body. Asian Journal of Pharmaceutical and Clinical Research. 12(10):193-196.

Pujiyanto, 2010, Pembuatan Karbon Aktif Super dari Batubara dan Tempurung Kelapa, Tesis, Universitas Indonesia, Jakarta.

Purwanto, J., 2011, Arang dari Limbah Tempurung Kelapa Sawit (Elaeis guineensis Jacq), Jurnal Penelitian Hasil Hutan, vol. 29, No.1, Balai Riset dan Standardisasi Industri, Banjarbaru

Anonim. 1995. Arang aktif teknis. Standar Nasional Indonesia (SNI) 06-3730- 1995. Jakarta.

Tresna, P. 2010. Merawat Kulit Wajah Tidak Bermasalah, UPI Press, Bandung.

Rowe R.C., Sheskey P.J., and Owen., 2006, Handbook of Pharmaceutical Excipients, 5th Edition, Pharmaceutical Press, London 